Louisiana State University

LSU Digital Commons

$10-1-2017$

\title{
The influence of föhn winds on Glacial Lake Washburn and palaeotemperatures in the McMurdo Dry Valleys, Antarctica, during the Last Glacial Maximum
}

\author{
M. K. Obryk \\ Portland State University \\ P. T. Doran \\ Louisiana State University \\ E. D. Waddington \\ University of Washington, Seattle \\ C. P. McKay \\ NASA Ames Research Center
}

Follow this and additional works at: https://digitalcommons.Isu.edu/geo_pubs

\section{Recommended Citation}

Obryk, M., Doran, P., Waddington, E., \& McKay, C. (2017). The influence of föhn winds on Glacial Lake Washburn and palaeotemperatures in the McMurdo Dry Valleys, Antarctica, during the Last Glacial Maximum. Antarctic Science, 29 (5), 457-467. https://doi.org/10.1017/S0954102017000062

This Article is brought to you for free and open access by the Department of Geology and Geophysics at LSU Digital Commons. It has been accepted for inclusion in Faculty Publications by an authorized administrator of LSU Digital Commons. For more information, please contact ir@lsu.edu. 
Portland State University

PDXScholar

\title{
The Influence of Föhn Winds on Glacial Lake Washburn and Palaeotemperatures in the McMurdo Dry Valleys, Antarctica, During the Last Glacial Maximum
}

\author{
Maciej Obryk \\ Portland State University \\ Peter Doran \\ Louisiana State University \\ Ed Waddington \\ University of Washington-Seattle \\ Chris McKay \\ NASA Ames Research Center
}

Follow this and additional works at: https://pdxscholar.library.pdx.edu/geology_fac

Part of the Geology Commons

Let us know how access to this document benefits you.

\section{Citation Details}

Obryk M.K., Doran P.T., Waddington E.D., Mckay C.P. 2017. The Influence of Föhn Winds on Glacial Lake Washburn and Palaeotemperatures in the McMurdo Dry Valleys, Antarctica, During the Last Glacial Maximum. Antarctic Science, 29(3)1-11.

This Article is brought to you for free and open access. It has been accepted for inclusion in Geology Faculty Publications and Presentations by an authorized administrator of PDXScholar. Please contact us if we can make this document more accessible: pdxscholar@pdx.edu. 


\title{
The influence of föhn winds on Glacial Lake Washburn and palaeotemperatures in the McMurdo Dry Valleys, Antarctica, during the Last Glacial Maximum
}

\author{
M.K. OBRYK ${ }^{1,2}$, P.T. DORAN ${ }^{2}$, E.D. WADDINGTON ${ }^{3}$ and C.P. MCKAY ${ }^{4}$ \\ ${ }^{1}$ Department of Geology, Portland State University, Portland, OR 97219, USA \\ ${ }^{2}$ Department of Geology and Geophysics, Louisiana State University, Baton Rouge, LA 70803, USA \\ ${ }^{3}$ Earth and Space Sciences, University of Washington, Seattle, WA 98195, USA \\ ${ }^{4}$ Space Science Division, NASA Ames Research Center, Moffett Field, CA 94035, USA \\ mobryk@pdx.edu
}

\begin{abstract}
Large glacial lakes, including Glacial Lake Washburn, were present in the McMurdo Dry Valleys, Antarctica, during the Last Glacial Maximum (LGM) despite a colder and drier climate. To address the mechanism capable of generating enough meltwater to sustain these large lakes, a conceptual model was developed based on the warming potential of infrequent contemporary föhn winds. The model suggests that föhn winds were capable of generating enough meltwater to sustain large glacial lakes during the LGM by increasing degree days above freezing (DDAF) and prolonging the melt season. A present-day relationship between infrequent summer föhn winds and DDAF was established. It is assumed that the Taylor Dome ice core record represents large-scale palaeoclimatic variations for the McMurdo Dry Valleys region. This analysis suggests that because of the warming influence of the more frequent föhn winds, summer DDAF in the McMurdo Dry Valleys during the LGM were equivalent to present-day values, but this enhanced summer signal is not preserved in the annually averaged ice core temperature record.
\end{abstract}

Received 11 July 2016, accepted 2 February 2017

Key words: degree days above freezing, hydrological modelling, LGM

\section{Introduction}

The McMurdo Dry Valleys, East Antarctica, is one of the most studied regions in Antarctica. The area $\left(\sim 4800 \mathrm{~km}^{2}\right)$ is ice-free due to the Transantarctic Mountains, which effectively block the ice sheet flow and decrease precipitation (Wharton et al. 1993, Doran et al. 2002, Gooseff et al. 2011, Levy 2013). Common features in these valleys are perennially ice-covered lakes located in closed basins. Due to a lack of outflow, a delicate climatic balance regulates the presence of these lakes. The existence of fresh liquid water in a climate with mean annual valley-bottom temperatures ranging from $-14.8^{\circ} \mathrm{C}$ to $-30.0^{\circ} \mathrm{C}$ (Doran et al. 2002) requires summer temperatures sufficiently high to induce glacial melt as the major source of liquid water, yet low enough to maintain the ice cover year-round (Chinn 1993). Cold winter temperatures allow for the replacement of the lake ice cover that is lost during the summer through evaporation and sublimation (Chinn 1993).

During the Last Glacial Maximum (LGM), the McMurdo Dry Valleys are hypothesized to have contained numerous large glacial lakes, even though the mean annual climate was apparently cooler and more arid than today (Hall et al. 2000, 2002, Steig et al. 2000). Hyper-arid conditions during the LGM might appear to be inconsistent with the development of large glacial lakes, which presents a conundrum as to the mechanism responsible for generating enough meltwater to sustain such large glacial lakes. Hall et al. (2010) and Hall \& Denton (1996) suggested that hyper-arid conditions would expose more bare ice on glaciers and decreased precipitation would expose more sediment, both acting to reduce albedo and enhance melt. Alternatively, Doran et al. (2002) proposed that warmer surface air temperatures were responsible for increased melt. Hyperarid conditions and warmer surface air temperatures are not mutually exclusive (Hall et al. 2010); however, a mechanism for increased air temperatures is required.

Recently, McGowan et al. (2014) argued against the existence of a large proglacial lake, Glacial Lake Victoria in northern McMurdo Dry Valleys, by attributing apparent palaeoshorelines to slope mass movement. While we do not question the geomorphological interpretation of Glacial Lake Victoria by McGowan et al. (2014), here we focus on the relatively narrow and steep-sided, extensively studied Taylor Valley and address the existence of a proglacial lake from a hydrologic perspective. In this paper, we investigate surface air temperature warming by the anomalous summer föhn winds in the present-day climate and the potential role of more frequent warm föhn winds on the existence of 


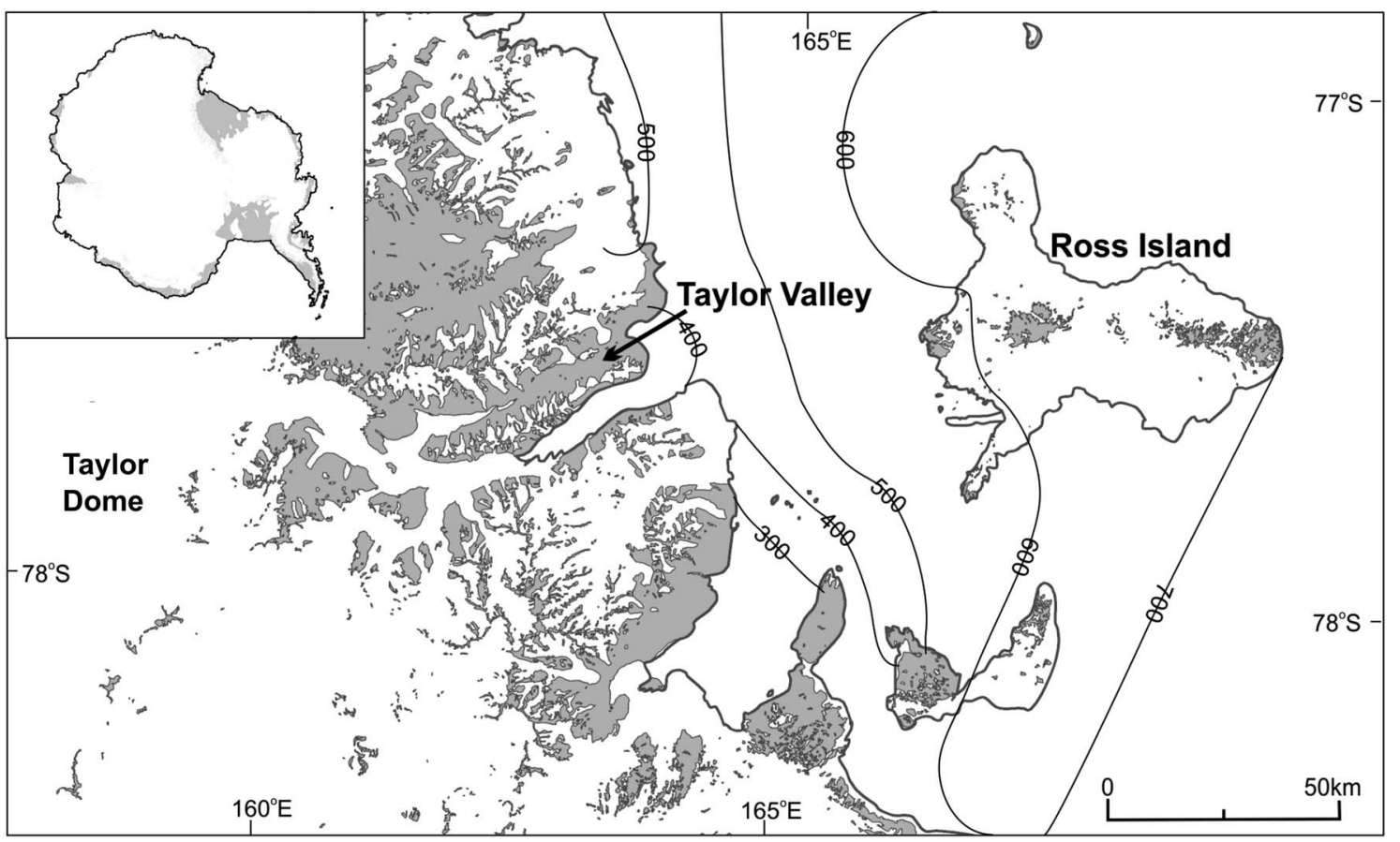

Fig. 1. Map of the McMurdo Dry Valleys region and approximate location of Taylor Dome. Contour lines represent elevation of the Ross Ice Sheet during the Last Glacial Maximum that dammed the mouth of Taylor (based on Denton \& Marchant 2000). The ice dam (not shown) allowed Taylor Valley to fill with meltwater to form Glacial Lake Washburn.

Glacial Lake Washburn, which was located in Taylor Valley during the LGM (Fig. 1). We developed a conceptual model based on the impact of the modernday anomalous summer föhn winds. This model can provide a mechanism capable of generating enough meltwater during the LGM to sustain large glacial lakes. This result has implications for interpretation of local seasonal palaeotemperatures during the LGM.

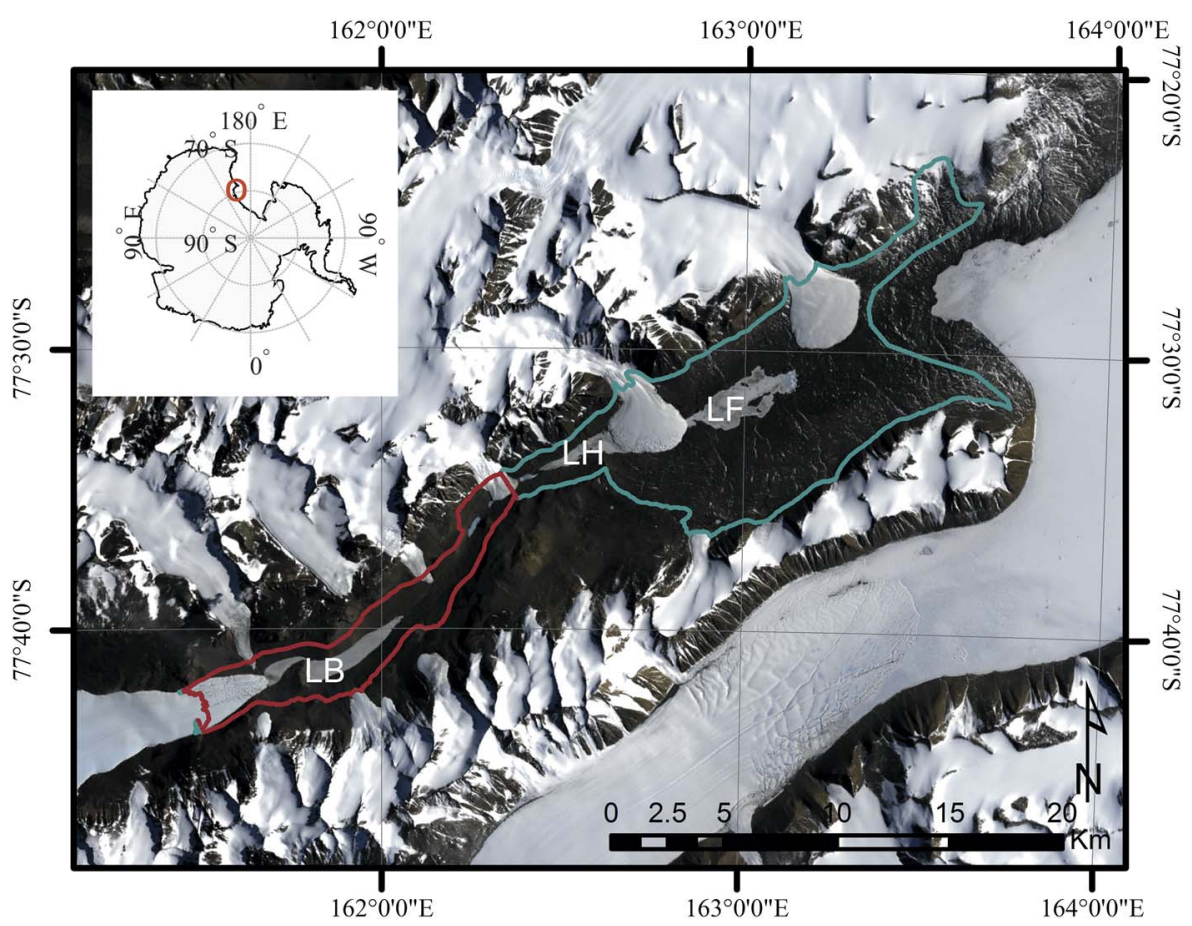

ig. 2. Landsat image of Taylor Valley showing locations of Lake Fryxell (LF), Lake Hoare (LH) and Lake Bonney (LB). The red contour represents small Glacial Lake Washburn extent at $300 \mathrm{~m}$ a.s.l. and the combined blue/red contours represent large Glacial Lake Washburn extent at $300 \mathrm{~m}$ a.s.l. Contours were calculated based on a $30 \mathrm{~m}$ digital elevation model. Ice dam locations (not shown) used to derive spatial extent of small and large proglacial lakes were approximated based on Hall et al. (2000) and Toner et al. (2013). 


\section{Regional settings and Glacial Lake Washburn}

Taylor Valley has two main basins, the Fryxell basin to the east and Bonney basin to the west, which are separated by an elevation threshold of $156 \mathrm{~m}$ a.s.l. Fryxell's basin is characterized by a broad valley that opens to McMurdo Sound with a sill near the coast at $74 \mathrm{~m}$ a.s.l. Lake Fryxell and Lake Hoare (current elevation 18 and $74 \mathrm{~m}$ a.s.l., respectively) occupy this end of the valley and are separated by the Canada Glacier (Fig. 2). The Bonney basin is characterized by a narrow, steep-sided valley occupied by Lake Bonney (current elevation $\sim 65 \mathrm{~m}$ a.s.1.), which is in contact on the western end with Taylor Glacier. These lakes are in closed basins, where the only loss of water from the lakes is through sublimation of the ice cover and evaporation at moats, which are small areas of open water between the ice cover and the shore. Moats allow stream flow to mix with liquid water in the lake. All of the melt occurs in the summer months of December and January.

During the LGM, Taylor Valley was filled by Glacial Lake Washburn, which is suggested to have reached a maximum elevation of $310 \mathrm{~m}$ a.s.1. (Stuiver et al. 1981), $336 \mathrm{~m}$ a.s.l. (Hall et al. 2000) and $300 \mathrm{~m}$ a.s.l. (Toner et al. 2013). The current $74 \mathrm{~m}$ a.s.l. spill point of Taylor Valley into McMurdo Sound indicates a requirement for an ice dam during the LGM in order to maintain an elevation $>300 \mathrm{~m}$ for Glacial Lake Washburn (Stuiver et al. 1981, Hall et al. 2000, Toner et al. 2013). The expansion and grounding of the Ross Ice Sheet allowed for formation of the ice dam (Fig. 1) and inundation of the valley (Stuiver et al. 1981, Hall \& Denton 2000).

Grounding of the Ross Ice Sheet is inferred from the distribution of the Ross Sea drift, which is distinguished by the presence of kenyte and basalt erratics, normally not found in Taylor Valley (Stuiver et al. 1981, Hall et al. 2000). Kenyte is a volcanic mineral found only on Ross Island, located $\sim 100 \mathrm{~km}$ east of Taylor Valley, and could only have been transported to Taylor Valley by a larger ice sheet (Fig. 1) (Stuiver et al. 1981, Hall et al. 2000). Evidence from the Ross Sea drift suggests that the northbound Ross Ice Sheet shifted its flow pattern toward the mouth of Taylor Valley to the west (Hall et al. 2000). The erratics are found at maximum elevation of $350 \mathrm{~m}$ a.s.l., marking the elevation limit of Ross Ice Sheet in Taylor Valley, providing a constraint for the grounding of the Ross Ice Sheet (Stuiver et al. 1981, Hall et al. 2000).

Taylor Valley was dammed from $\sim 23000$ to 8340 ${ }^{14} \mathrm{C}$ yr вP (Hall \& Denton 2000). The elevation and timing of Glacial Lake Washburn high stands are inferred from soluble salt distributions (Toner et al. 2013) and the radiocarbon dating of benthic algal mats along ancient shorelines and deltas on the slopes of Taylor Valley (Hall \& Denton 2000). Soluble salts accumulate along the wetted margin of the lakes through evapoconcentration
(Barrett et al. 2009) and are indicative of maximum palaeolake level stands (Toner et al. 2013). Of 232 radiocarbon dated algal samples, 119 samples are located above the spill point of Taylor Valley into McMurdo Sound and require the existence of an ice dam resulting in large Glacial Lake Washburn (Hall \& Denton 2000). Alternatively, these samples indicate formation of meltwater ponds on the edge of the Ross Ice Sheet where it intruded into Taylor Valley, suggesting a small Glacial Lake Washburn extent (Toner et al. 2013).

The spatial extent of the ice dam has been debated. Stuiver et al. (1981) and Hall et al. (2000) suggested that the Ross Ice Sheet terminated at the mouth of Taylor Valley; whereas, Toner et al. (2013) proposed that the Ross Ice Sheet advanced to the Lake Bonney basin, occupying the entire eastern Taylor Valley (Fig. 2). The advancement of the Ross Ice Sheet to the Bonney basin is inferred from differences in soluble salt distribution between eastern and western Taylor Valley (Toner et al. 2013), which appears to be inconsistent with several radiocarbon dated algal mats in eastern Taylor Valley (Hall \& Denton 2000) and palaeolimnological reconstruction based on a sediment core obtained from Lake Fryxell (Wagner et al. 2006). Since the location of the Ross Ice Sheet influenced the size of Glacial Lake Washburn (Fig. 2), the minimum and maximum Ross Ice Sheet extents will be considered in this paper. The two proposed ice sheet configurations have implications on the size of the proglacial lakes. We refer to them as large Glacial Lake Washburn (Hall et al. 2000) and small Glacial Lake Washburn (Toner et al. 2013) (Fig. 2).

Geologic and geomorphological data provide robust evidence for the existence of Glacial Lake Washburn (Stuiver et al. 1981, Hall \& Denton 2000, Hall et al. 2000,

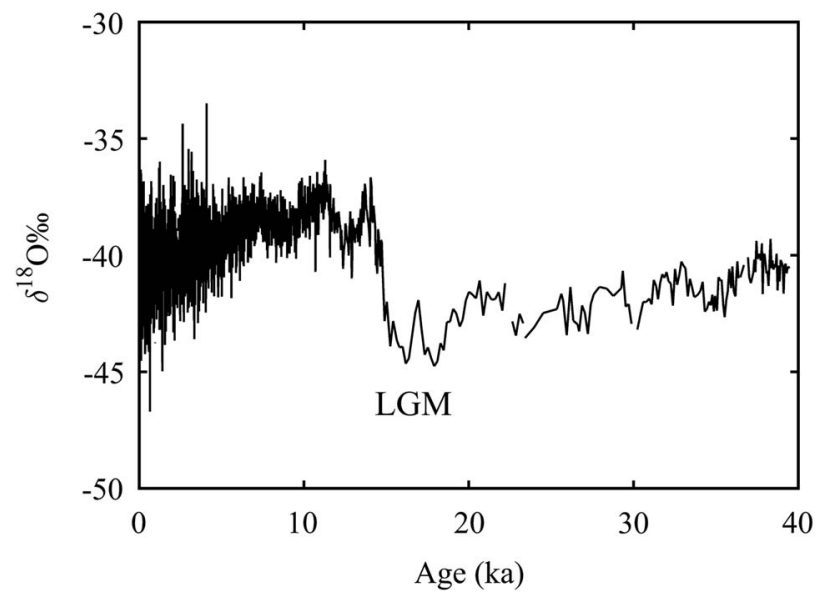

Fig. 3. Taylor Dome $\delta^{18} \mathrm{O}$ record. The depletion of $\delta^{18} \mathrm{O}$ during the Last Glacial Maximum (LGM) indicates temperatures were $4-8^{\circ} \mathrm{C}$ colder than present day (Steig et al. 2000). 
Toner et al. 2013); however, the climate reconstructions propose that the McMurdo Dry Valleys experienced a colder, drier and windier climate during the LGM. The $\delta^{18} \mathrm{O}$ record from the Taylor Dome ice core at the head of the McMurdo Dry Valleys indicates that the annual average temperature was $4-8^{\circ} \mathrm{C}$ colder during the LGM than at present (Steig et al. 2000) (Fig. 3). The expansion of the Ross Ice Sheet displaced the moisture source $\sim 1000 \mathrm{~km}$ farther away than present (Hinkley \& Matsumoto 2001, Hall et al. 2010). Based on Taylor Dome radar stratigraphy, Morse et al. (1998) suggested that this ice sheet expansion reorganized synoptic weather systems and, as a result, changed the trajectories of moisture-bearing storms.

Currently, two predominant wind trajectories affect Taylor Dome climate; dry south-westerly katabatics and moisture-bearing southerly winds (föhn) (Morse et al. 1998). However, during the LGM, this pathway was either reduced or eliminated, significantly decreasing precipitation (Morse et al. 1998). The Taylor Dome record also exhibits high levels of aerosol loading, such as dust (Ca) and salts (Na) from $\sim 27-12 \mathrm{ka}$ BP and low ${ }^{10} \mathrm{Be}$ concentrations during the highest stands of Glacial Lake Washburn, indicative of persistent windier conditions (Steig et al. 2000, Grootes et al. 2001, Hinkley \& Matsumoto 2001, Morse et al. 2007). The dominance of dust over salts is consistent with expansion of the Ross Ice Sheet (Hinkley \& Matsumoto 2001). The relatively low concentrations of ${ }^{10} \mathrm{Be}$, suggest dilution by snowfall to a greater extent than inferred from the existing layer thicknesses in the ice core. The implication is that some snow containing ${ }^{10} \mathrm{Be}$ was blown away by strong winds (Morse et al. 2007). It is important to consider that low precipitation rates at Taylor Dome during the LGM are not necessarily indicative of more arid conditions in the McMurdo Dry Valleys. Moisture for local alpine glaciers in the McMurdo Dry Valleys is derived from the Ross Sea, and delivered by easterly winds (Fountain et al. 1999). The easterly wind pattern was most probably also active during the LGM, due to a thermal contrast between the cold Ross Ice Sheet and the relatively warm ice-free McMurdo Dry Valleys. Yet, during the LGM, an expanded Ross Ice Sheet would displace the moisture source significantly (Hall et al. 2010). Hence, despite the presence of easterly winds during the LGM, the McMurdo Dry Valleys could have received less moisture than present. The resulting hyper-arid climate probably led to the retreat of alpine glaciers located in Taylor Valley, in comparison to their present-day positions (Hall et al. 2000, Higgins et al. 2000). Exposed blue ice on the glacial surfaces (Hall et al. 2010) along with warming associated with föhn winds (Doran et al. 2008) were hypothesized to be responsible for a large meltwater flux to inundate Taylor Valley.

\section{Anomalous summer föhn winds}

The McMurdo Dry Valleys climate is punctuated by episodes of strong summer westerly winds that are associated with adiabatic warming and low relative humidity (McKendry \& Lewthwaite 1990, Nylen et al. 2004, Doran et al. 2008, Speirs et al. 2010). Past research has referred to these winds interchangeably as katabatic and föhn winds (e.g. Nylen et al. 2004, Doran et al. 2008, Speirs et al. 2010, Steinhoff et al. 2013). Speirs et al (2010) have made the case that these are all föhn winds resulting from a mountain wave effect caused by complex topography due south of the valleys. We use the föhn terminology here, regardless of how these strong westerlies were referred to in the literature. The southerly air masses are channelled to western McMurdo Dry Valleys, due to a pressure gradient, through a mountain gap between Antarctic Plateau and Royal Society Range (Speirs et al. 2010, Steinhoff et al. 2013). The occurrence and strength of the föhn winds in the McMurdo Dry Valleys themselves are driven by a pressure gradient of low-pressure (cyclonic activity) due east of the McMurdo Dry Valleys over the Ross Sea, and a high-pressure system over the Antarctic Plateau due west of the McMurdo Dry Valleys (Doran et al. 2008, Speirs et al. 2010). The föhn winds undergo compressional warming (due to a dry adiabatic lapse rate) as they descend to the bottom of the valleys (Speirs et al. 2010, Steinhoff et al. 2013). Strong summer föhn events cause an anomalous increase of valley-bottom temperatures, which can persist for a few days following a wind event (Nylen et al. 2004). The summer föhn winds are rare, but their effect on local hydrological processes is profound, as they can increase maximum surface air temperature by $4.8^{\circ} \mathrm{C}$ (Doran et al. 2008). Enhanced glacial melt associated with higher temperatures results in high stream flow and an increase in lake levels. The summer of 2001-02 (hereafter, referred to as the flood year) experienced an unusually large increase (up to $\sim 1 \mathrm{~m}$ ) in Taylor Valley lake levels (Doran et al. 2008). The main discriminating factor between the flood year and the extremely cold and dry summer the previous year (non-flood year) was an increase in summer föhn wind frequency, resulting in maximum summer surface air temperatures reaching $9.2^{\circ} \mathrm{C}$ (Doran et al. 2008).

The maximum summer temperatures have been recognized to increase degree days above freezing (DDAF), which extend the duration of the normally short period when the temperatures are high enough to generate glacial melt that feeds into the lakes (Doran et al. 2008). The flood year experienced 56.8 DDAF, prolonging the melt season, which resulted in significant increase in lake levels (Doran et al. 2008). In comparison, the previous nonflood year experienced only 5.4 DDAF and a very small lake level change (Doran et al. 2008). The two seasons are distinguished by the strength of the pressure gradient 


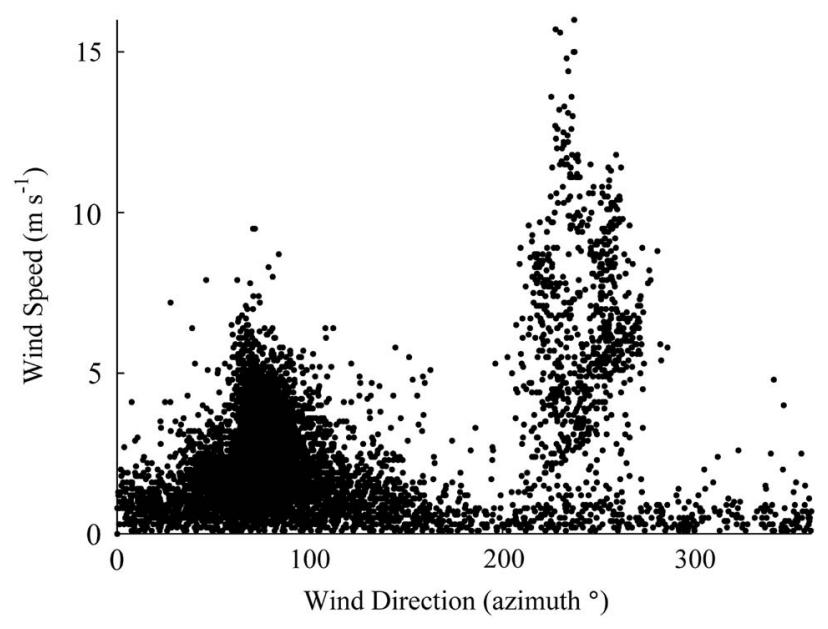

Fig. 4. A typical example of bimodal distribution of wind direction and speed in Taylor Valley, McMurdo Dry Valleys, (2010-11 season). The $180-360^{\circ}$ range is down-valley winds. Data obtained from www.mcmlter.org.

(large gradient during the flood year), which is partially responsible for channelling strong föhn winds through Taylor Valley during the summer (Speirs et al. 2010, Steinhoff et al. 2013) and intrusion of warm air masses into the Antarctic interior during the flood year (Steinhoff et al. 2014). We hypothesize that the high frequency and seasonal persistence of summer föhn winds during the LGM (as in the flood year), at a time when there was significantly more low-elevation ice in Taylor Valley than today (i.e. the Ross Ice Sheet damming the east end of Taylor Valley), was responsible for an increase of DDAF in the tail of the distribution and associated meltwater production, and for filling the Taylor Valley basin to create Glacial Lake Washburn.

\section{Methods}

Meteorological data (surface temperature and wind speed/direction) pertaining to this study were obtained from Lake Hoare, Lake Bonney and Taylor Dome meteorological stations. Taylor Valley data used in this study were collected by Campbell Scientific dataloggers (CR10 and 21X) at 30 s sampling intervals and stored as averages over intervals of 15-20 min (Doran et al. 1995, 2002). Air temperature was measured at $3 \mathrm{~m}$ height using Campbell 207 and 107 temperature probes (Doran et al. 1995). Wind speed and direction were obtained with R.M. Young model 05103 wind monitors (Doran et al. 1995). Taylor Valley data are available at the McMurdo LongTerm Ecological Research project database (www. mcmlter.org). Taylor Dome data were collected using Campbell Scientific CR10 dataloggers and averaged over $3 \mathrm{~h}$ intervals. Air temperature was measured at $3 \mathrm{~m}$ height using Thermometrics NTC glass-enclosed thermistors. Wind speed and direction were obtained with R.M. Young model 05103 wind monitor. Several meteorological stations are located across Taylor Dome that show distinct microclimates that cannot be explained by latitude and altitude alone (Waddington \& Morse 1994). However, because of limited overlapping data with Taylor Valley's meteorological stations, Taylor Dome data used in this study were obtained from weather station $20 \mathrm{C}$ only (located near the centre of Taylor Dome; see Waddington \& Morse 1994 for 20C weather station location). Within Taylor Valley, Lake Hoare has the longest uninterrupted record, whereas the Lake Bonney station is located the farthest from the coast. The Lake Bonney station is least influenced by the coastal winds because of its proximity to the Antarctic Plateau and associated föhn winds, and topographical separation between eastern and western Taylor Valley (Doran et al. 2002). As such, the Lake Bonney station resembles the LGM configuration when sea ice extent was significantly larger. Summer föhn events were defined as westerly winds (between $180^{\circ}$ and $360^{\circ}$ ) with wind speed $>5 \mathrm{~m} \mathrm{~s}^{-1}$, and lasting $>6 \mathrm{~h}$. The large threshold selected for wind direction ensures that all westerly winds were selected (Fig. 4). The DDAF and wind run (total amount or distance of the wind travel over a certain point for the period in question) for summer föhn events only were calculated for each summer (DJF) from 1995-2012.

Years with a high frequency of summer föhn wind events are associated with large lake level increases in Taylor Valley (Doran et al. 2008). To convert lake level increases to seasonal volumetric changes, hypsometric data were generated for each basin in Taylor Valley. An integration of hypsometric data allowed for conversion of elevation (ma.s.1.) to volume. To reconstruct Glacial Lake Washburn, a digital elevation model (DEM) of the entire Taylor Valley with $30 \mathrm{~m}$ resolution was modified by incorporating an ice dam at a fixed elevation of $350 \mathrm{~m}$ a.s.1. to account for the Ross Ice Sheet expansion into Taylor Valley during the LGM. Large Glacial Lake Washburn was reconstructed by georeferencing a schematic representing Ross Ice Sheet extent in Taylor Valley (obtained from Hall et al. 2000) over the DEM of Taylor Valley. The boundary of small Glacial Lake Washburn was set at the divide between eastern and western Taylor Valley (based on Toner et al. 2013). The hypsometries of small and large Glacial Lake Washburn basins were calculated in ArcGIS 10.1 (Table S1 found at http://dx.doi.org/10.1017/S0954102017000062).

In order to estimate DDAF during modern and LGM climates, temperature probability distributions for the McMurdo Dry Valleys were estimated based on three components:

$$
T_{p}(t)=T_{\text {seas }}(t)+T_{W X}(t)+T_{w w}(t),
$$


Table I. Constants used in the temperature probability distribution calculations.

\begin{tabular}{lll}
\hline & Modern climate & Last Glacial Maximum climate \\
\hline$T_{\text {ave }}$ & $-20^{\circ} \mathrm{C}$ & $-25^{\circ} \mathrm{C}$ \\
$T_{\text {amp }}$ & $12^{\circ} \mathrm{C}$ & $12^{\circ} \mathrm{C}$ \\
$\alpha$ & 0.5 & 0.5 \\
$\Delta t$ & 1 day & 1 day \\
$W X_{\text {amp }}$ & $5^{\circ} \mathrm{C}$ & $5^{\circ} \mathrm{C}$ \\
$d t_{\text {min }}$ wind & 1 day & 1 day \\
$d t_{\text {max }}$ wind & 4 days & 7 days \\
$d T_{\text {min wind }}$ & $8^{\circ} \mathrm{C}$ & $8^{\circ} \mathrm{C}$ \\
$d T_{\text {max }}$ wind & $20^{\circ} \mathrm{C}$ & $20^{\circ} \mathrm{C}$ \\
$N_{\text {windlyear }}$ & 12 & 24 \\
Run length & 100 years & 100 years \\
\hline
\end{tabular}

where $T_{\text {seas }}$ is seasonal temperature variability, $T_{W X}$ represents weather systems passing over the region and $T_{w w}$ is the warming effect of the westerly winds. Seasonal temperature variability is expressed as:

$$
T_{\text {seas }}(t)=T_{\text {ave }}+T_{\text {amp }} \sin (2 \pi t),
$$

where $T_{a v e}$ is annually averaged temperature and $T_{a m p}$ is seasonal temperature amplitude. Weather system $\left(T_{W X}\right)$ is represented as a dimensionless red noise:

$$
R N(t+\Delta t)=\alpha R N(t)+\left(1-\alpha^{2}\right)^{1 / 2} \varepsilon(t),
$$

where $\alpha$ is a parameter that controls persistence of the red noise over a time interval $\Delta t$, and $\varepsilon$ represents white noise generated from a normal distribution with zero mean and unit variance, which is scaled by a constant $W X_{a m p}$ in units ${ }^{\circ} \mathrm{C}$. Westerly winds are represented by the number $\left(N_{\text {windlyear }}\right)$ of warm episodes of length randomly selected between $d t_{\text {min wind }}$ and $d t_{\text {max wind }}$, and with the degree of warming chosen randomly between $d T_{\text {min wind }}$ and $d T_{\text {max wind }}$. The $N_{\text {windlyear }}$ events each year are assigned randomly throughout the year. The statistical model was run for 100 years. The constants used are summarized in Table I.

The hydrologic budget of Taylor Valley lakes is difficult to determine because volumetric gain and loss variables cannot be constrained individually (based on current available data). For the lake to be sustained, inflow has to be equal to outflow. Lake volume changes can be expressed as:

$$
\frac{d V}{d t}=G Q+Q_{s t r}+Q_{\text {seep }}+[P-S-E] A,
$$

where $\mathrm{d} V / \mathrm{d} t$ is the volume change rate, $G Q$ is direct glacial melt, $Q_{s t r}$ is inflowing stream discharge, $Q_{\text {seep }}$ is shallow ground-water recharge, $P$ is precipitation, $S$ is sublimation, $E$ is evaporation and $A$ is surface area of the lake. Equation (4) can be solved numerically using an iterative approach. Recognizing that surface area of a lake $(A)$ at a specific height $(h)$ times change in elevation equals to change in volume:

$$
d V=A(h) d h,
$$
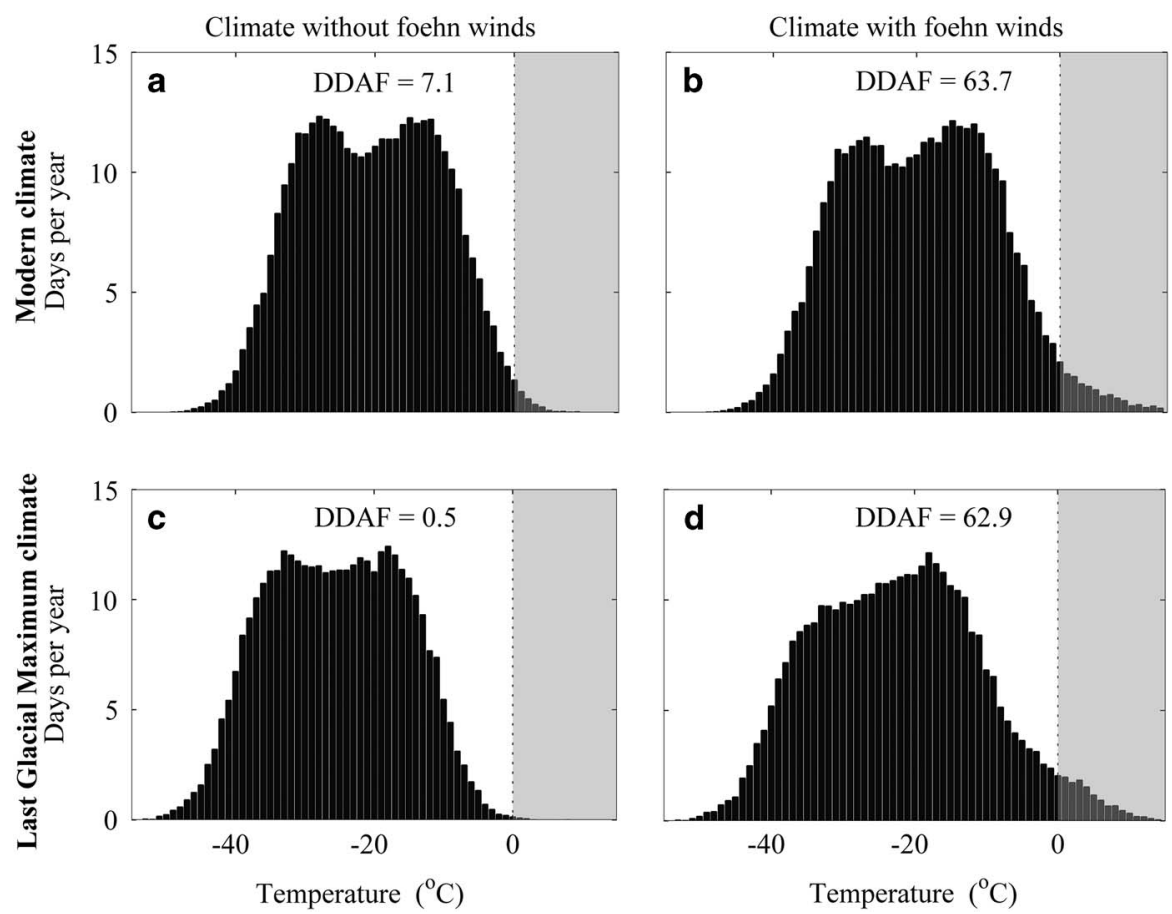

Fig. 5. Possible daily temperature distributions for modern and Last Glacial Maximum (LGM) climates with and without the warming influence of föhn winds. Modern climate assumes mean surface air temperature of $-20^{\circ} \mathrm{C}$ and 12 föhn events, whereas LGM climate assumes mean annual surface air temperature of $-25^{\circ} \mathrm{C}$ and 24 föhn events. Bin width $=1{ }^{\circ} \mathrm{C}$. a. Modern climate without föhn wind warming. b. Modern climate with föhn wind warming. c. LGM climate without föhn wind warming. d. LGM climate with föhn wind warming. Both modern and LGM climates show increased number of degree days above freezing (DDAF) due to the warming associated with föhn winds (see Methods for calculations). The bimodal distributions arise because temperatures are more similar day-to-day near the solstices than near the equinoxes, where temperature warms or cools rapidly as the seasons change. 
and expressing Eq. (5) as a function of time:

$$
\frac{d V}{d t}=A(h) \frac{d h}{d t}
$$

allows Eq. (4) to be rewritten as:

$$
\frac{d h}{d t}=\frac{G Q+Q_{s t r}+Q_{\text {seep }}}{A(h)}+[P-S-E] .
$$

Given tabulated basin hypsometry $(A)$ and assumed loss rates $(S$ and $E$ ), the maximum elevation of Glacial Lake Washburn can be determined based on the gain rate set to flood year volumetric change rate $\left(G Q+Q_{\text {str }}+Q_{\text {seep }}\right)$, excluding $P$ on the conservative assumption that any snowfall would be removed by sublimation when airborne due to the high frequency of winds before its contribution to the volumetric gain. The numerical model was run for 12000 years (from $22-10 \mathrm{ka}$ вP). Volumetric gain rate is defined as the sum of the first three terms in Eq. (4):

$$
f(t)=G Q(t)+Q_{s t r}(t)+Q_{\text {seep }}(t) .
$$

In order to test the feasibility of Taylor Valley inundation, we set the maximum flow rate (flood year volume) in Eq. (8) at $16 \mathrm{ka} \mathrm{BP}$, simulated using a spline function (note: the timing of the maximum flow rate is not intended to represent Glacial Lake Washburn lake level evolution during the LGM; rather, it shows possible maximum lake elevation under different loss rates):

$f(t)=\left\{\begin{array}{c}Q_{\text {init }}+\left(Q_{\text {max }}-Q_{\text {init }}\right) *\left[a(t)^{2}+b(t)^{3}\right] t<-16000 \\ Q_{\text {final }}+\left(Q_{\text {max }}-Q_{\text {final }}\right) *\left[a(t)^{2}+b(t)^{3}\right] t \geq-16000\end{array}\right.$,

where $Q_{\text {init }}$ is the initial volumetric gain rate of $1 \times 10^{4}$ $\left(\mathrm{m}^{3} \mathrm{a}^{-1}\right), Q_{\max }$ is the maximum volumetric gain rate of $1.82 \times 10^{7}\left(\mathrm{~m}^{3} \mathrm{a}^{-1}\right), Q_{\text {final }}$ is the final volumetric gain rate of $1.3 \times 10^{4}\left(\mathrm{~m}^{3} \mathrm{a}^{-1}\right)$, and coefficients $a$ and $b$ are set to 3 and -2 , respectively. Loss rates per unit lake area $(S$ and $E$ ) for the duration of each model scenario are assumed to be constant and range between 0.455 and $0.70 \mathrm{~m} \mathrm{a}^{-1}$.

\section{Results}

A correlation between summer (DJF) föhn winds at Lake Hoare meteorological station between 1995 and 2012, quantified as wind run, and summer DDAF was found $(r=0.83, P<0.001, n=18)$. The positive correlation indicates that summer föhn winds are associated with an increase in DDAF. Distributions of daily surface air temperatures with and without föhn wind warming, both in the modern climate and in the LGM climate, based on 100 year realizations of a statistical model, are shown in Fig. 5. The number of DDAF during both modern and

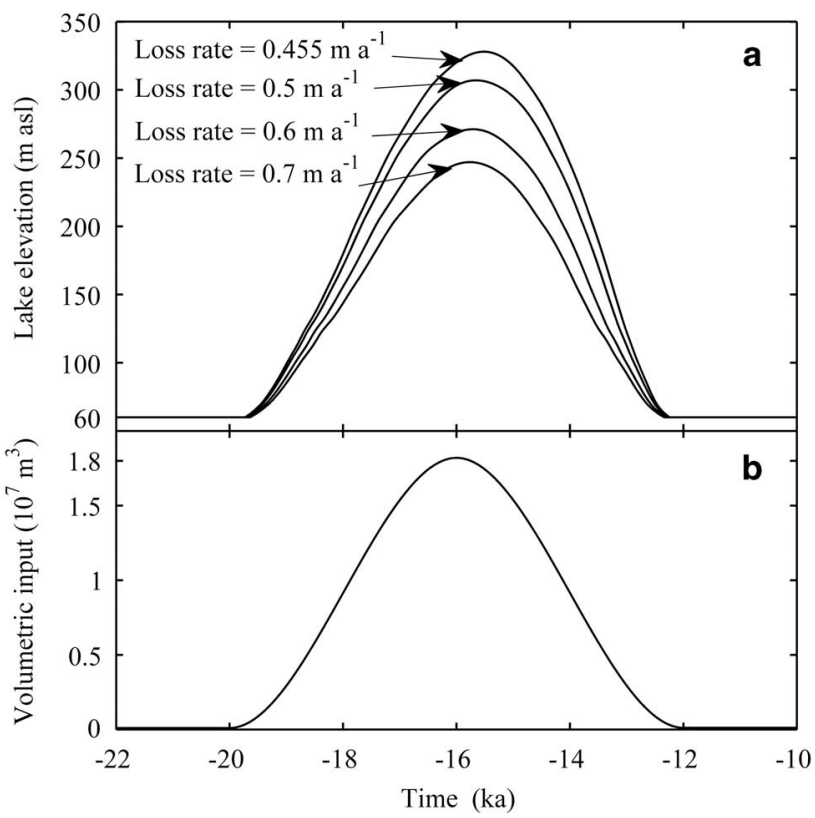

Fig. 6. Small Glacial Lake Washburn elevation over time assuming flood-year-like conditions during the Last Glacial Maximum. a. Elevation of the lake is highly sensitive to volumetric loss rates, which are a function of the surface area of a lake. Loss rates per unit area (sublimation and evaporation) are assumed to be constant for the duration of each model run. b. Volumetric inflow rate is simulated using a transient spline function with maximum inflow rate equal to flood year volume change (direct precipitation onto the lake is not accounted for).

LGM climate are strongly influenced by the frequency of föhn winds (shaded areas in Fig. 5). Increased frequency and duration of föhn winds during the LGM is capable of rising DDAF to flood-year-like conditions.

Based on a numerical model and hypsometries of small and large Glacial Lake Washburn, only small Glacial Lake Washburn was reproduced to elevations suggested by the geologic and geomorphological evidence. The lake level changes for small Glacial Lake Washburn, assuming different outflow rates, are summarized in Fig. 6a and associated volumetric inflow is shown in Fig. 6b (as previously noted, Fig. 6 represents possible maximum lake levels, not lake level evolution). The minimum time to fill Taylor Valley to small Glacial Lake Washburn can be calculated by setting a constant gain rate instead of the spline function in Fig. 6b. Contribution from $P$ is not included. Assuming that flood-year-like conditions were persistent each season, it would take $\sim 900$ years to flood Taylor Valley to the extent of small Glacial Lake Washburn.

While limited modern overlapping data exist between Taylor Dome and Taylor Valley ( 2 years), an example of temperature warming due to infrequent föhn winds at 


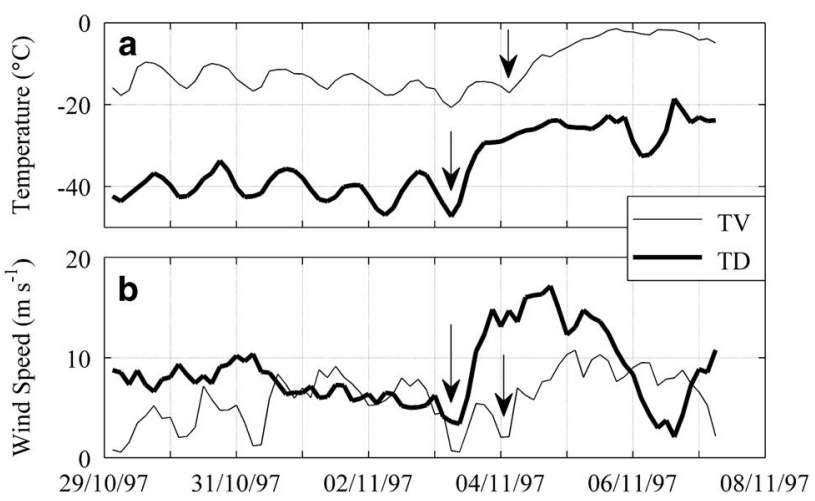

Fig. 7. An example of late-spring warming at Taylor Dome (TD) and Lake Bonney, Taylor Valley (TV). a. Temperature at TD and TV. b. Wind speed at TD and TV. Arrows indicate beginning of a change in wind regime and associated temperature increases at both locations. Lag in both wind speed and temperature increase at both locations is $\sim 20$ hours.

both locations is shown in Fig. 7. During early November 1997, after several days of steady cold temperatures (apart from a diurnal signal) and moderate and relatively steady winds at Taylor Dome, wind speed doubled in a few hours on 3 November and temperature rose by $\sim 20^{\circ} \mathrm{C}$ and stayed warm thereafter. At Taylor Valley, $\sim 20 \mathrm{~h}$ later, wind speed changed direction from up- to down-valley (not shown) and rose from near zero to $>10 \mathrm{~m} \mathrm{~s}^{-1}$, and temperature also rose $>15^{\circ} \mathrm{C}$ to nearly freezing point and stayed high thereafter.

\section{Discussion}

Föhn winds are frequently experienced during the winter and can increase surface air temperature by $>40^{\circ} \mathrm{C}$ (Speirs et al. 2010) for several days. Although rare, summer föhn winds have a large impact on local hydrological and biological processes by increasing DDAF and, by association, enhancing the melt season. Our results show that summer föhn winds are significantly correlated with DDAF. The associated increase of DDAF during the flood year was responsible for the increase of meltwater that entered the lakes (Doran et al. 2008).

In Fig. 7, we exemplify the influence of down-valley winds on temperature, which, if frequent, have a profound effect on hydrological response in Taylor Valley (increase of DDAF). Albeit, this example shows temperature warming during late spring, a higher frequency of such events (as suggested during LGM based on ice core record) can increase melt season duration, similar to the flood year, providing a mechanism for raising temperature above freezing point, increasing DDAF and meltwater production, and ultimately inundating Taylor Valley.
The colder (annually averaged) surface air temperatures during the LGM do not preclude summer air temperatures from rising above freezing because more frequent summer föhn winds could have increased DDAF, enhancing glacial melt. While Taylor Dome ice core data suggest windier conditions during the LGM, we cannot make direct inferences that more frequent and stronger föhn existed in Taylor Valley and we rely on our model results. We illustrate the importance of warming by the föhn winds in Fig. 5. The statistical model allowed us to quantify the impact of föhn winds, based on a few simple assumptions about weather. A modern climate is approximated by assuming mean annual air temperature of $-20^{\circ} \mathrm{C}$ and 12 föhn warming events per year, and the LGM climate assumes mean annual air temperature of $-25^{\circ} \mathrm{C}$ and 24 föhn warming events per year. Our results for modern climate (Fig. 5a \& b) are comparable with those found by Doran et al. (2008). For both modern and LGM scenarios, föhn winds are responsible for a dramatic increase in DDAF because the melt days are entirely due to the right-hand tail of the distribution. The higher frequency of föhn winds during the LGM is capable of increasing the DDAF from nearly zero (Fig. 5c) to $>60$ (Fig. 5d), which is sufficient to generate a flood-year-like melt season, despite colder than average annual temperatures.

Due to the low accumulation rate, the Taylor Dome ice core time series for the LGM has been averaged over many years (Steig et al. 2000). This means that the stable isotope record does not and cannot record seasonality and its extremes. However, we suggest that it is solely the warm tail of the seasonal temperature distribution (Fig. 5) that is responsible for high proglacial lake levels. The warmer and more frequent summer föhn winds during the LGM were responsible for increased DDAF (Fig. 5d) and, by association, increased seasonal melt. The windier conditions based on the Taylor Dome ice core record could have increased DDAF, enabling prolonged melt seasons that would generate enough meltwater to fill the Taylor Valley basin to the observed Glacial Lake Washburn levels, despite apparent colder average temperatures preserved in the ice core record.

Large lakes, such as Glacial Lake Washburn, require either an increase in meltwater, or a decrease in the loss terms in Eq. (4), in comparison to today's levels. The flood year is an example of how meltwater can increase significantly due to an increased frequency/intensity of summer föhn winds. We use the flood year as an analogue for conditions that may have sustained large glacial lakes during the LGM. In this conceptual model, it is assumed that loss rates ( $S$ and $E$ ) remain constant per unit area; hence, the total volumetric loss will vary with surface area of the lake. The surface area ratio of large and small Glacial Lake Washburn to the total surface area of all modern lakes in Taylor Valley is 
12:1 and 3:1, respectively. Hence, volumetric loss rate for Glacial Lake Washburn was between 12 and 3 times larger than for contemporary lakes, which represents the factors by which volumetric input would need to increase from today in order to keep lake levels stable at the higher elevations.

The ratio of volumes of meltwater generated during the flood year and the non-flood year is $\sim 3: 1$. During the nonflood year, lake levels remained largely unchanged, i.e. the volumetric input balanced the volumetric loss. So the flood year analogue, if sustained over time, could create small Glacial Lake Washburn because the flood year generated just enough water required to sustain small Glacial Lake Washburn in a steady state. However, it is important to note that during the LGM there was significantly more low-elevation ice provided by the Ross Ice Sheet at the east end of the valley than today (Fig. 1). The low-elevation ice contributes considerably to the seasonal melt (Doran et al. 2008), further supporting the conceptual model. The ice dam topography, as proposed by Denton \& Marchant (2000), suggests that the Ross Ice Sheet was debris-covered and sloping toward Taylor Valley (Fig. 1), significantly increasing the catchment area of Glacial Lake Washburn and its potential for capturing meltwater. Debris-laden ice would lower albedo and enhance meltwater potential. While the conceptual model emphasizes the importance of meltwater generation due to föhn winds only, we recognize that the additional melt sources could have potentially supported large Glacial Lake Washburn and/ or supported small Glacial Lake Washburn, even with loss rates higher than today.

An additional source of meltwater for polar lakes that abut glaciers comes from the subaqueous melt of the glacial face. One such example is closed-basin perennially ice-covered Lake Untersee located in Dronning Maud Land, East Antarctica. The ice cover of Lake Untersee does not melt around the edges of the lake during the summer (Andersen et al. 2011), contrary to Taylor Valley lakes, inhibiting stream inflow (if present) from entering the water column. The primary source of meltwater for Lake Untersee is assumed to be water mass contributed by the ablation of the subaqueous part of the glacier (Wand et al. 1997, Andersen et al. 2011). The flow of the glacier into the basin provides a continuous source of new water. Shortwave radiation that penetrates the perennial ice cover is highly attenuated, allowing only several percent of incident solar radiation to penetrate to the bottom of the ice cover (Spigel \& Priscu 1998). However, a combination of ice melt due to the contact with underice water and the amount of solar radiation reaching the subaqueous glacier that abuts Lake Untersee is sufficient to sustain the lake. The surface area ratio of Lake Untersee to small Glacial Lake Washburn is 3:1; hence, Lake Untersee is an analogue for subaqueous meltwater generation (capable of generating one third of meltwater required to sustain small Glacial Lake Washburn) that is independent of surface air temperatures, a process that operated during the LGM.

Our numerical model shows a high sensitivity of the lake level to the volumetric loss rates (Fig. 6a), which scale with the surface area of the lake. Figure 6a validates the conceptual model and provides minimum volumetric gain boundary conditions for the existence of small Glacial Lake Washburn. In order to sustain small Glacial Lake Washburn with flood year gain rate only, the loss rate per unit area $\left(S\right.$ and $E$ ) needs to be $\leq 0.5 \mathrm{~m} \mathrm{a}^{-1}$. Higher loss rates would require additional meltwater, which could have been provided by subaerial and subaqueous melt of the low-elevation Ross Ice Sheet terminating in Lake Washburn as discussed earlier (which is not included in our simulations). Current mean ablation rates (ice loss by any means) in Taylor Valley lakes range from $0.6-1.0 \mathrm{~m} \mathrm{a}^{-1}$ (Dugan et al. 2013). However, these ablation rates account for a lake ice melt that feeds back into the water column during the summer (Dugan et al. 2013), overestimating the loss rate per unit area. Sublimation/evaporation rate only, can be approximated by considering ablation during a cold summer when the lake ice melt is minimal. Based on the seasonal ablation rates reported in Dugan et al. (2013), the loss rate of contemporary lakes per unit area $(S$ and $E$ ) is $\sim 0.35-0.59 \mathrm{~m} \mathrm{a}^{-1}$. Assuming persistent flood-year-like inflow flux during the LGM, there would be no difficulty filling small Glacial Lake Washburn in the time available ( 900 years) considering that Glacial Lake Washburn existed for more than 10000 years.

\section{Conclusions}

The closest palaeoclimatic record for the McMurdo Dry Valleys is the Taylor Dome ice core record. Based on the $\delta^{18} \mathrm{O}$ record in the ice core, annually averaged temperatures at Taylor Dome during the LGM appear to have been $4-8^{\circ} \mathrm{C}$ colder than present, and we expect that mean annual temperatures in the McMurdo Dry Valleys were also lower at the LGM. The cold and hyperarid climate during the LGM may appear to be inconsistent with the formation and sustainability of large glacial lakes, if the mean annual temperature is thought to be the key climate parameter.

We have shown that there is, in fact, no inconsistency, because the mean annual temperature is not the key parameter. The ice core record cannot capture the variance because of greater seasonality; however, melting occurs only on the warmest summer days, i.e. in the extreme tail of the daily temperature distribution, and warm summer days can occur despite very cold mean temperatures if the variance in daily temperatures is sufficiently large. 
We identify the key factor to be episodic föhn winds, which, as extreme events in the summer weather patterns, can cause significant warming during spring and early summer. The modern föhn winds have a profound effect on climate and lake levels in Taylor Valley by pushing temperatures above the melting point on a few summer days. In years with more föhn episodes than normal, the increase in DDAF due to the föhn winds enhances the melt season, and that increased melt produces an increase in lake levels.

The existence of Glacial Lake Washburn implies that seasonality was enhanced during the LGM, such that temperatures in the McMurdo Dry Valleys on the warmest summer days were comparable to today, perhaps largely due to an increase in frequency and intensity of warm föhn winds. Persistence of summer föhn winds during the LGM would have increased DDAF, and produced the required meltwater for Glacial Lake Washburn, despite colder mean annual temperatures. Our work suggests that föhn winds were responsible for formation of large glacial lakes during the LGM by increasing the summer temperatures despite colder annual average temperatures derived from the ice core $\delta^{18} \mathrm{O}$ record.

\section{Acknowledgements}

This research was supported by National Science Foundation (NSF) Office of Polar Programs (grants 9810219, 0096250, 0832755, 1041742, 1115245, 8915924, 9221261 and 9412644). Logistical support was provided by the US Antarctic Program through funding from NSF. We would like to acknowledge David Morse for installing automated weather stations at Taylor Dome, and Hans-Peter Marshall for processing and providing meteorological data from Taylor Dome. In addition, we would like to thank two anonymous reviewers whose comments improved this work.

\section{Author contribution}

MKO contributed to conceptual hydrologic model design, model analysis, data interpretation and article preparation. PTD and CPM contributed to conceptual hydrologic model design, data interpretation and manuscript revisions. EDW contributed to numerical model design, data interpretation and manuscript revisions.

\section{Supplemental material}

A supplemental table will be found at http://dx.doi.org/ 10.1017/S0954102017000062.

\section{References}

Andersen, D.T., Sumner, D.Y., Hawes, I., Webster-Brown, J. \& McKaY, C.P. 2011. Discovery of large conical stromatolites in Lake Untersee, Antarctica. Geobiology, 9, 280-293.

Barrett, J.E., GoosefF, M.N. \& Takacs-Vesbach, C. 2009. Spatial variation in soil active-layer geochemistry across hydrologic margins in polar desert ecosystems. Hydrology and Earth Systems Sciences, 13, 2349-2358.

Chinn, T.J. 1993. Physical hydrology of the dry valley lakes. Antarctic Research Series, 59, 1-51.

Denton, G.H. \& Marchant, D.R. 2000. The geologic basis for a reconstruction of a grounded ice sheet in McMurdo Sound, Antarctica, at the Last Glacial Maximum. Geografiska Annaler Physical Geography, 82A, 167-211.

Doran, P.T., Dana, G.L., Hastings, J.T. \& Wharton JR, R.A. 1995. McMurdo Dry Valleys Long-Term Ecological Research (LTER): LTER automatic weather network (LAWN). Antarctic Journal of the United States, 30(5), 276-280.

Doran, P.T., McKay, C.P., Clow, G.D., Dana, G.L., Fountain, A., Nylen, T. \& Lyons, W.B. 2002. Valley floor climate observations from the McMurdo Dry Valleys, Antarctica, 1986-2000. Journal of Geophysical Research - Atmospheres, 107, 10.1029/2001JD002045.

Doran, P.T., McKay, C.P., Fountain, A.G., Nylen, T., McKnight, D.M., Jaros, C. \& Barrett, J.E. 2008. Hydrologic response to extreme warm and cold summers in the McMurdo Dry Valleys, East Antarctica. Antarctic Science, 20, 499-509.

Dugan, H.A., Obryk, M.K. \& Doran, P.T. 2013. Lake ice ablation rates from permanently ice-covered Antarctic lakes. Journal of Glaciology, 59, 491-498.

Fountain, A., Lyons, W.B., Burkins, M.B., Dana, G.L., Doran, P.T., Lewis, K.J., McKnight, D., Moorhead, D.L., Parsons, A.N., Priscu, J.C., Wall, D.H., Wharton, R.A. \& Virginia, R.A. 1999. Physical controls on the Taylor Valley ecosystem, Antarctica. BioScience, 49, 961-972.

Gooseff, M.N., McKnight, D.M., Doran, P.T., Fountain, A.G. \& Lyons, W.B. 2011. Hydrological connectivity of the landscape of the McMurdo Dry Valleys, Antarctica. Geography Compass, 5, 666-681.

Grootes, P.M., Steig, E.J., Stuiver, M., Waddington, E.D. \& Morse, D.L. 2001. The Taylor Dome Antarctic ${ }^{18} \mathrm{O}$ record and globally synchronous changes in climate. Quaternary Research, 56, 289-298.

Hall, B.L. \& Denton, G.H. 1996. Deglacial chronology of the western Ross Sea. Antarctic Journal of the United States, 31(2), 78-80.

Hall, B.L. \& Denton, G.H. 2000. Radiocarbon chronology of Ross Sea drift, eastern Taylor Valley, Antarctica: evidence for a grounded ice sheet in the Ross Sea at the Last Glacial Maximum. Geografiska Annaler - Physical Geography, 82A, 305-336.

Hall, B.L., Denton, G.H. \& Hendy, C.H. 2000. Evidence from Taylor Valley for a grounded ice sheet in the Ross Sea, Antarctica. Geografiska Annaler - Physical Geography, 82A, 275-303.

Hall, B.L., Denton, G.H., Overturf, B. \& Hendy, C.H. 2002. Glacial Lake Victoria, a high-level Antarctic lake inferred from lacustrine deposits in Victoria Valley. Journal of Quaternary Science, 17, 697-706.

Hall, B.L., Denton, G.H., Fountain, A.G., Hendy, C.H. \& Henderson, G.M. 2010. Antarctic lakes suggest millennial reorganizations of Southern Hemisphere atmospheric and oceanic circulation. Proceedings of the National Academy of Sciences of the United States of America, 107, 21 355-21 359.

Higgins, S.M., Hendy, C.H. \& Denton, G.H. 2000. Geochronology of Bonney Drift, Taylor Valley, Antarctica: evidence for interglacial expansions of Taylor Glacier. Geografiska Annaler - Physical Geography, 82A, 391-409.

HinkLey, T.K. \& Matsumoto, A. 2001. Atmospheric regime of dust and salt through 75,000 years of Taylor Dome ice core: refinement by measurement of major, minor, and trace metal suites. Journal of Geophysical Research - Atmospheres, 106, 18 487-18 493. 
Levy, J. 2013. How big are the McMurdo Dry Valleys? Estimating icefree area using Landsat image data. Antarctic Science, 25, 119-120.

McGowan, H.A., NeIL, D.T. \& SpeIrs, J.C. 2014. A reinterpretation of geomorphological evidence for Glacial Lake Victoria, McMurdo Dry Valleys, Antarctica. Geomorphology, 208, 200-206.

McKendRy, I.G. \& Lewthwaite, E.W.D. 1990. The vertical structure of summertime local winds in the Wright Valley, Antarctica. BoundaryLayer Meteorology, 51, 321-342.

Morse, D.L., Waddington, E.D. \& Rasmussen, L.A. 2007. Ice deformation in the vicinity of an ice-core site at Taylor Dome, Antarctica, and a derived accumulation rate history. Journal of Glaciology, 53, 449-460.

Morse, D.L., Waddington, E.D. \& Steig, E.J. 1998. Ice age storm trajectories inferred from radar stratigraphy at Taylor Dome, Antarctica. Geophysical Research Letters, 25, 3383-3386.

Nylen, T.H., Fountain, A.G. \& Doran, P.T. 2004. Climatology of katabatic winds in the McMurdo Dry Valleys, southern Victoria Land, Antarctica. Journal of Geophysical Research - Atmospheres, 109, 10.1029/2003JD003937.

Speirs, J.C., Steinhoff, D.F., McGowan, H.A., Bromwich, D.H. \& Monaghan, A.J. 2010. Föhn winds in the McMurdo Dry Valleys, Antarctica: the origin of extreme warming events. Journal of Climate, 23, 3577-3598

Spigel, R.H. \& Priscu, J.C. 1998. Physical limnology of the McMurdo Dry Valley lakes. Antarctic Research Series, 72, 153-187.

Steig, E.J., Morse, D.L., Waddington, E.D., Stuiver, M., Grootes, P.M., Mayewski, P.A., Twickler, M.S. \& Whitlow, S.I. 2000. Wisconsinan and Holocene climate history from an ice core at Taylor Dome, western Ross Embayment, Antarctica. Geografiska Annaler - Physical Geography, 82A, 213-235.
Steinhoff, D.F., Bromwich, D.H. \& Monaghan, A. 2013. Dynamics of the föhn mechanism in the McMurdo Dry Valleys of Antarctica from Polar WRF. Quarterly Journal of the Royal Meteorological Society, 139, 1615-1631.

Steinhoff, D.F., Bromwich, D.H., Speirs, J.C., McGowan, H.A. \& Monaghan, A.J. 2014. Austral summer föhn winds over the McMurdo Dry Valleys of Antarctica from Polar WRF. Quarterly Journal of the Royal Meteorological Society, 140, 1825-1837.

Stuiver, M., Denton, G.H., Hughes, T.J. \& Fastbrook, J.L. 1981. History of the marine ice sheet in West Antarctica during the last glaciation: a working hypothesis. In Denton, G.H. \& Hughes, T.H., eds. The last great ice sheets. New York, NY: Wiley, 319-436.

Toner, J.D., Sletten, R.S. \& Prentice, M.L. 2013. Soluble salt accumulations in Taylor Valley, Antarctica: implications for paleolakes and Ross Sea Ice Sheet dynamics. Journal of Geophysical Research - Earth Surface, 118, 198-215.

Waddington, E.D. \& Morse, D.L. 1994. Spatial variations of local climate at Taylor Dome, Antarctica: implications for paleoclimate from ice cores. Annals of Glaciology, 20, 219-225.

Wagner, B., Melles, M., Doran, P.T., Kenig, F., Forman, S.L., Pierau, R. \& Allen, P. 2006. Glacial and postglacial sedimentation in the Fryxell Basin, Taylor Valley, southern Victoria Land, Antarctica. Palaeogeography Palaeoclimatology Palaeoecology, 241, 320-337.

Wand, U., Schwarz, G., Bruggemann, E. \& Brauer, K. 1997. Evidence for physical and chemical stratification in Lake Untersee (central Dronning Maud Land, East Antarctica). Antarctic Science, 9, $43-45$.

Wharton, R.A., McKay, C.P., Clow, G.D. \& Andersen, D.T. 1993. Perennial ice covers and their influence on Antarctic lake ecosystems. Antarctic Research Series, 59, 53-70. 